\section{Correlation between the type of bcr-ab/ transcripts and blood cell counts in chronic myeloid leukemia - a possible influence of mdr1 gene expression}

\author{
Gueorgui Balatzenko, ${ }^{1}$ \\ Babu Rao Vundinti, \\ Guenova Margarita ${ }^{3}$
}

${ }^{1}$ Laboratory of Cytogenetics and Molecular Biology, National Specialized

Hospital for Active Treatment of

Hematological Diseases, Sofia, Bulgaria;

2Institute of Immunohematology, ICMR,

KEM Hospital, Parel, Mumbai, India;

${ }^{3}$ Laboratory of Hematopathology and

Immunology, National Specialized

Hospital for Active Treatment of

Hematological Diseases, Sofia, Bulgaria

\section{Abstract}

The impact of $B C R-A B L$ mRNA type (b3a2 vs. b2a2) on chronic myeloid leukemia (CML) phenotype is still a subject of controversies. We searched for a correlation between the $B C R$ $A B L$ transcripts type and CML patients' characteristics, including MDR1 gene expression. Ninety-eight untreated chronic phase CML patients were studied. The type of $B C R-A B L$ fusion transcripts and $M D R 1$ gene expression were determined by reverse transcriptase polymerase chain reaction. B3a2 and b2a2 transcripts were found in 53 [54\%] and 44 [45\%] patients, respectively. One patient coexpressed b3a2/b2a2 and was excluded from analysis. The only difference in the clinical characteristics between the two groups was the platelets count, that was higher in $\mathrm{b} 3 \mathrm{a} 2^{(+)}$ patients $\left[791.3 \pm 441.3 \times 10^{9} / \mathrm{L}\right.$ vs. $440.4 \pm 283.4 \times$ $10^{9} / \mathrm{L}$ in b2a2 ${ }^{(+)} ; \mathrm{P}=0.007$ ]. MDR1 over-expression $\left[M D R 1^{(+)}\right]$was observed in 48 patients (49.5\%), more frequently in older patients $>60$ years [71\% (24/34) vs. $38 \%$ (24/63) in younger; $\mathrm{P}=0.008]$, and was associated with a lower white blood cells $(\mathrm{WBC})$ count [105.5 $\pm 79.8 \times$ $10^{9} / \mathrm{L}$ vs. $143.6 \pm 96.5 \times 10^{9} / \mathrm{L}$ in $M D R 1^{(-)}$cases; $\mathrm{P}=0.047]$. On performing the analysis only within the $M D R l^{(+)}$group, the $\mathrm{b}_{3} \mathrm{a}_{2}{ }^{(+)}$cases were characterized with a significantly higher platelets count $\left[908.7 \pm 470.1 \times 10^{9} / \mathrm{L}\right.$ vs. $\left.472.9 \pm 356.1 \times 10^{9} / \mathrm{L} ; \mathrm{P}=0.006\right]$ and a lower WBC count $\left[85.4 \pm 61.2 \times 10^{9} / \mathrm{L}\right.$ vs. $130 \pm 93.9 \times 10^{9} / \mathrm{L}$; $\mathrm{P}=0.004$ ) compared to $\mathrm{b} 2 \mathrm{a} 2^{(+)}$patients. No similar differences were found between b3a $2^{(+)}$and b2a $2^{(+)}$groups with normal MDR1 levels. These results indicate that the type of
$B C R-A B L$ transcripts correlates with the hematological parameters of CML, however only in the subgroup of patients characterized by $M D R 1$ over-expression.

\section{Introduction}

Chronic myeloid leukemia (CML) is characterized by the consistent involvement of the Philadelphia chromosome (Ph) and the BCR$A B L$ fusion gene, which derives from the reciprocal translocation $\mathrm{t}(9 ; 22)(\mathrm{q} 34 ; \mathrm{q} 11)$ between chromosome 9 and 22. In almost all CML patients, the breakpoint in the $B C R$ gene involves the Major breakpoint cluster region (M-bcr). The position of the breakpoint within the M-bcr, after exon b2 (e13) or exon b3 (e14) determines two main types of the fused $B C R$ $A B L$ mRNA defined as $\mathrm{b} 2 \mathrm{a} 2$ and $\mathrm{b} 3 \mathrm{a} 2$ transcripts differing by 75 nucleotides. These transcripts encode two 210-kDa tyrosine kinase proteins (p210 $\left.{ }^{B C R-A B L}\right)$, which differ by 25 amino acids respectively. ${ }^{1}$

The impact of M-bcr breakpoint position on disease phenotype and its prognosis has been a subject of controversies for a long time. Several reports have suggested that the type of the chimeric mRNA (b2a2 or b3a2) is associated with differences in the clinical and hematological characteristics of CML patients and prognosis, despite that others failed to confirm any significant correlation. ${ }^{2-6}$ One of the most interesting finding is the association of $\mathrm{b} 3 \mathrm{a} 2$ type of fusion transcript with a higher platelet counts with some evidence in favor ${ }^{7-9}$ and some against. ${ }^{10-12}$ A great deal of the discrepancy or discordance between the various studies could be due to qualitative and/or quantitative differences in patient or sample selection. ${ }^{12}$ However, the contradictory results might also be attributed to the presence of unknown biological factors, which can affect the obtained results. This hypothesis is supported by the observation of Shepherd et al.,1995 who failed to detect any significant difference in the presented features at diagnosis for patients with either b2a2 or b3a2 transcripts. However, in a subgroup of patients whose presenting white blood cell (WBC) count was $<100 \times 10^{9} / \mathrm{L}$, those with b3a2 transcript did have a significantly higher platelet count. ${ }^{13} 0$ n the other hand, it has been reported that early chronic phase CML patients with very similar characteristics (i.e. thrombocytosis, WBC count $<50 \times 10^{9} / \mathrm{L}$, and age $>50$ years) were characterized with elevated levels of Multidrug Resistance 1 (MDRI) gene expression. ${ }^{14}$ Therefore, it might be possible, that the level of $M D R 1$ gene expression in the individual CML patients could influence the association between the different $B C R-A B L$ tran-
Correspondence: Gueorgui Balatzenko, Laboratory of Cytogenetics and Molecular Biology, National Specialized Hospital for Active Treatment of Hematological Diseases, 6, Plovdivsko pole Str., 1756 Sofia, Bulgaria.

Tel. +3592.9701137 - Fax: $+3592+9701.107$.

E-mail: balatzenko@hotmail.com

Key words: chronic myeloid leukemia, $B C R-A B L$ breakpoint, b3a2, b2a2, MDR1 gene expression.

Acknowledgements: this study was supported by the National Research Fund, Bulgarian Ministry of Education and Science (BIn-03/2006). The authors express their gratitude to Dr. A. Stoimenov for his contribution to molecular studies.

Contributions: GB, MG, study design, molecular analysis, data collection, results interpretation and manuscript writing; VBR, study design, results interpretation and critical review.

Conflict of interest: the authors report no conflicts of interest.

Received for publication: 28 December 2010. Accepted for publication: 8 March 2011.

This work is licensed under a Creative Commons Attribution 3.0 License (by-nc 3.0).

(C) Copyright G. Balatzenko et al., 2011

Licensee PAGEPress, Italy

Hematology Reports 2010; 3:e3

doi:10.4081/hr.2011.e3

scripts and disease features.

MDR1 gene, located on chromosome $7 \mathrm{q} 21$ encodes a $170 \mathrm{\kappa D}$ membrane transporter P-glycoprotein [P-gp] that acts as an energydependent, efflux pump. Over-expression of MDR1/P-gp confers resistance to the cytotoxic effects of a broad range of structurally unrelated compounds (i.e. anthracyclines, epipodophyllotoxins and vinca alkaloids) and is one of the most common mechanisms of so-called multidrug resistance (MDR) in various malignancies. Over-expression of the MDR1 gene has been found in a significant proportion of patients with different hematological malignancies and several observations suggest its poor prognostic value. ${ }^{15}$

The data concerning the incidence of $M D R 1$ over-expression in chronic phase CML patients are controversial ranging from total absence to presence in $20-65 \%$ and up to in $100 \%$ of patients. ${ }^{14,16-20}$ Even less is known about the relationship of the MDR1 levels to clinical data at presentation in CML. ${ }^{14}$ The association between the $M D R 1$ levels and type of $B C R-A B L$ transcripts to our knowledge has not been studied yet.

In this study we analyzed the correlations between the BCR-ABL mRNA types and CML patients' characteristics at presentation, including the possible impact of MDR1 mRNA levels. 


\section{Materials and Methods}

\section{Patients}

Ninety-eight untreated consecutive chronic phase CML patients (59 males and 39 females) with a mean age $50.5 \pm 14.1$ years were included in this study. All patients signed informed consent form before entry on study. The diagnosis of CML was established on the basis of the peripheral blood parameters and morphological analysis of peripheral blood and bone marrow aspirates and confirmed by the presence of Philadelphia chromosome and/or fusion $B C R-A B L$ gene by conventional cytogenetics and reverse transcription polymerase chain reaction (RT-PCR) respectively.

\section{Methods}

RNA extraction and complementary DNA (cDNA) synthesis

Bone marrow and/or peripheral blood samples were collected after obtaining informed consent at the time of CML diagnosis. Mononuclear cells were separated after lysis of red blood cells with a lysis buffer $(155 \mathrm{mM}$ NH4Cl, 10 mM KHCO3, 0.1 mM EDTA). ${ }^{21}$ Total cellular RNA was isolated using Trizol Reagent (Invitrogen) according to the manufacturer's protocol. cDNA was synthesized by reverse transcription of $1 \mu \mathrm{g}$ of RNA in a reaction medium with final volume of $20 \mathrm{ul}$ containing: 1x first-strand buffer, $200 \mathrm{U}$ MMLV reverse transcriptase (Thermo Scientific, ABGene, UK), $1 \mathrm{mM}$ of each dNTPs, $20 \mathrm{U}$ RNAsin (Promega) and $5 \mu \mathrm{M}$ random hexamers (Roche Diagnostics), by consecutive incubation of the samples at $37^{\circ} \mathrm{C}$ for 1 hour and at $99^{\circ} \mathrm{C}$ for 3 minutes. Random hexamers instead of specific primers were used so that different PCR analyses could be performed on the same cDNA sample.

\section{PCR assay for $B C R-A B L$}

The presence of $\mathrm{P} 210^{\mathrm{BCR}-\mathrm{ABL}}$ rearrangement and the type of the respective fusion transcripts were determined by a single step RTPCR using primers (ABL-a3B: gtttgggcttcacaccattcc/BCR-b1A: gaagtgtttcagaagcttctcc) and according to the protocol, recommended by the European BIOMED 1 Concerted Action for standardization of MRD studies in acute leukaemia. ${ }^{22}$ Briefly, 5 uL of cDNA were amplified in a $50 \mu \mathrm{L}$ medium containing $1 \mathrm{x}$ PCR buffer, $2.5 \mathrm{mM} \mathrm{MgCl} 2,200 \mu \mathrm{M}$ each of dNTPs, $1 \mathrm{U}$ Taq polymerase (Invitrogen), and $400 \mathrm{nM}$ of each of upstream and downstream primers. The mixture was incubated at $94^{\circ} \mathrm{C}$ for $30 \mathrm{sec}$; $65^{\circ} \mathrm{C}$ for $60 \mathrm{sec} ; 72^{\circ} \mathrm{C}$ for $60 \mathrm{sec}$ with a total 35 cycles using Mastercycler Gradient (Eppendorf). Amplification products were run in a $2 \%$ agarose gel (Invitrogene) after stain- ing with ethidium bromide, visualized after UV irradiation and photographed. For all RT-PCR reactions, K562 (b3a2) and/or BV173 (b2a2) cell lines were used as a positive control and RNA from healthy donors as a negative control.

\section{PCR assay for MDR1 gene expression}

PCR was carried-out by simultaneous amplification of the MDR1 and $\beta_{2}$-microglobulin $\left(\beta_{2}-M\right)$ RNA, as an internal control. Briefly, 5 $\mu \mathrm{l}$ of cDNA were amplified in $50 \mu \mathrm{L}$ medium, containing 1x PCR buffer, $1.5 \mathrm{mM} \mathrm{MgCl} 2 ; 200$ $\mu \mathrm{M}$ each of dNTPs; $1 \mathrm{U}$ Taq polymerase (Promega) and $0.4 \mathrm{pM}$ each of primers MDR1TL9: ttcaaacttgtcacaatgcaga cagcagga / MDR1TL10: ggttgcaggcctccatttataatggcacaa (for $M D R 1)$; together with B2-M1: acccccactgaaaaagatga/B2-M2: atcttcaaacctccatgatg primers (for $\beta 2-M$ ) (Genset). ${ }^{23}$ The reaction started with denaturation at $94^{\circ} \mathrm{C}$ for $5 \mathrm{~min}$; proceeded with 25 cycles of amplification at $94^{\circ} \mathrm{C}$ for $30 \mathrm{sec}$; at $57^{\circ} \mathrm{C}$ for $30 \mathrm{sec}$; at $72^{\circ} \mathrm{C}$ for $30 \mathrm{sec}$; and terminated at $72^{\circ} \mathrm{C}$ for $10 \mathrm{~min}$. Amplification products were run in a $3 \%$ agarose gel, stained with ethidium bromide and visualized after UV. The reaction conditions were chosen so that none of the RNAs analyzed reached a plateau at the end of the amplification procedure, i.e. when amplification proceeds exponentially at a constant efficiency and the yield of the RT-PCR product is proportional to the starting amount of the template. Therefore, no product of MDR1 amplification was seen in CML samples with normal level of MDR1 gene expression, as well as in samples from healthy donors used as negative controls. In these cases the only visible product of PCR was the intensive band corresponding to $\beta 2-M$ RNA (MDR1-negative). All samples that showed clearly visible product of $M D R 1$ amplification with intensity lower, equivalent or higher than $\beta 2-M$ product were considered as MDR1-positive (i.e. with over-expression). RNA from healthy volunteers was included as a negative control, and RNA from an acute lymphoblastic leukaemia (FAB L3 subtype) patient with manifested drug resistance and immunologically confirmed high level of P-gp expression was used as a positive control.

Strict precautions to avoid carryover contaminations were followed as recommended by Kwok \& Higushi. ${ }^{24}$

\section{Statistical analysis}

The type of BCR-ABL transcripts and MDR1 gene expression status were analyzed in correlation to age, sex and peripheral blood parameters (hemoglobin, leukocyte count and platelets). All statistical analyses were performed using the SPSS 9.0 software. The Wilcoxon Mann-Whitney test was used to compare the distributions of numerical-valued variables between patients with b3a2 and with b2a2 transcripts, as well as between subgroups of patients with normal and with elevated levels of $M D R 1$ gene expression. Univariate differences between categorical variables subsets were evaluated by Fisher's exact test. P-values of 0.05 or less were considered to be of statistical significance.

\section{Results}

In this study we analyzed the type of $B C R$ $A B L$ transcripts and $M D R 1$ gene expression in 98 untreated adult patients with chronic phase CML and correlated the findings with clinical, hematological and molecular data (Table 1).

\section{Types of $B C R-A B L$ transcripts in} correlation to basic patients' characteristics at presentation

RT-PCR was used to confirm the diagnosis of CML by detection of fusion $B C R-A B L$ gene, and to reveal the type of transcripts depending on the $\mathrm{M}-b c r$ region breakpoint location. All studied patients were found to be $B C R-A B L$ positive. Fifty-three of them expressed $\mathrm{b} 3 \mathrm{a} 2$ transcripts [54\%], whereas forty-four of the remaining cases were positive for b2a2 transcripts [45\%]. Co-expression of both types of transcripts (b2a2 (+) b3a2) was observed in one patient [1\%], who was excluded from further analysis. All patients were analyzed to determine the relationship between the type of transcripts and the presenting features at diagnosis including age, sex, white blood cells (WBC) count, platelets and hemoglobin $(\mathrm{Hb})$ concentration. The platelets count was statistically higher in the subgroup of patients expressing b3a2, than those with $\mathrm{b} 2 \mathrm{a} 2$ transcript $\left(791.3 \pm 441.3 \times 10^{9} / \mathrm{L}\right.$ vs. $\left.440.4 \pm 283.4 \times 10^{9} / \mathrm{L} ; \mathrm{P}=0.007\right)$. The remaining variables were not significantly different in both groups (b2a2 and b3a2) ( $\mathrm{P}>0.05)$. (Table 2).

\section{MDR1 expression in correlation to basic patients' characteristics at presentation}

The pattern of MDR1 amplification in CML

Table 1. Basic demographic and hematological features of patients included in the study.

\begin{tabular}{lc} 
Total number of patients $[\mathrm{n}=]$ & 98 \\
Gender & \\
$\quad$ Males $[\mathrm{n}=]$ & $59[60 \%]$ \\
Females $[\mathrm{n}=]$ & $39[40 \%]$ \\
Age & \\
$\quad$ Mean \pm SD [years] & $50.5 \pm 14.12$ \\
\hline WBC & $125.2 \pm 90.4$ \\
$\quad$ Mean \pm SD $\left[\times 10^{9} / \mathrm{L}\right]$ & \\
Platelets & $615.8 \pm 406.3$ \\
$\quad$ Mean \pm SD $\left[\times 10^{9} / \mathrm{L}\right]$ & \\
\hline Hemoglobin & $111.7 \pm 27.0$ \\
\hline Mean \pm SD $[\mathrm{g} / \mathrm{L}]$ &
\end{tabular}


patients varied considerably from case to case with a different intensity of the reaction ranging from negative to strongly positive. RT-PCR revealed moderate or strong positive reaction, corresponding to over-expression of MDR1 gene $\left[M D R l^{(+)}\right]$, in 48 out of 97 patients (49.5\%). No product of MDR1 amplification, corresponding to a normal level of MDR1 expression $\left[M D R 1^{(-)}\right]$, was seen in the remaining 49 patients (50.5\%).

The mean WBC count was significantly lower in $M D R I^{(+)}$patients $\left[105.5 \pm 79.8 \times 10^{9} / \mathrm{L}\right.$ vs. $143.6 \pm 96.5 \times 10^{9} / \mathrm{L}(\mathrm{P}=0.047)$ in $\left.M D R 1^{(-)}\right]$. In addition, $M D R 1$ gene over-expression was significantly more frequent in elderly patients with age $>60$ years - $71 \%(24 / 34)$, compared to that in younger patients - $38 \%$ (24/63) $(\mathrm{P}=0.008)$, although, the mean age did not differ between the $M D R I^{(+)}$and $M D R 1^{-}$patients $(\mathrm{P}>0.05)$. No significant differences in regard to sex, type of $B C R-A B L$ transcripts, platelet count and hemoglobin concentration between the two groups of patients expressing either normal or elevated $M D R 1$ levels were found (P>0.05) (Table 3).

\section{The impact of MDR1 status}

of patients on the association between the types of $B C R-A B L$ transcripts with basic characteristics at the presentation

In order to determine the impact of MDR1 status of patients on the association of the type of transcripts with clinical and biological characteristics, both groups were additionally divided into subgroups with normal and elevated MDR1 levels. The analysis of the $\mathrm{b} 3 \mathrm{a} 2$ patients revealed a lower mean WBC count in $M D R 1^{(+)}$cases compared to the respective value in $M D R 1^{(-)}$patients $\left[85.4 \pm 61.2 \times 10^{9} / \mathrm{L}\right.$ vs. $\left.150.8 \pm 86.6 \times 10^{9} / \mathrm{L}^{(-)}(\mathrm{P}=0.004)\right]$. However, no differences in the patients' characteristics were found in the b2a2 group according to the MDR1 status. Appling the same approach by stratifying the patients according to the MDR1 status, no significant differences in patients' characteristics were observed between b3a2 and $\mathrm{b} 2 \mathrm{a} 2$ cases with normal MDR1 levels (Table 4). In contrast, within the group with MDR1 over-expression, the b3a2-positve cases were characterized with a significantly higher platelets count $(\mathrm{P}=0.006)$ and lower WBC count $(\mathrm{P}=0.004)$ compared to b2a2-positive patients (Table 4)

\section{Discussion}

Data concerning the association between the type of $B C R-A B L$ transcripts and CML patient characteristics remain contradictory. Therefore, we compared the main clinical fea-
Table 2. Association between clinical and laboratory data and the type of fusion $B C R$ $A B L$ transcripts for the 97 chronic myeloid leukemia patients.

\begin{tabular}{|c|c|c|c|}
\hline \multirow[t]{2}{*}{ Parameter } & \multicolumn{2}{|c|}{ BCR-ABL transcripts } & \multirow[t]{2}{*}{$\mathbf{P}$} \\
\hline & b3a2 & b2a2 & \\
\hline Patients [n=] & $53[55 \%]$ & $44[45 \%]$ & \\
\hline $\begin{array}{l}\text { Age } \\
\text { Mean } \pm \text { SD [years] }\end{array}$ & $51.0 \pm 13.7$ & $49.9 \pm 4.8$ & NS \\
\hline $\begin{array}{l}\text { Gender } \\
\text { Males }[n=] \\
\text { Females }[n=]\end{array}$ & $\begin{array}{l}28 \text { [53\%] } \\
31 \text { [70\%] }\end{array}$ & $\begin{array}{l}25[47 \%] \\
13[30 \%]\end{array}$ & NS \\
\hline $\begin{array}{l}\text { WBC } \\
\text { Mean } \pm \text { SD }\left[\times 10^{9} / \mathrm{L}\right]\end{array}$ & $119.5 \pm 81.7$ & $132.4 \pm 100.8$ & NS \\
\hline $\begin{array}{l}\text { Platelets } \\
\text { Mean } \pm \mathrm{SD}\left[\times 10^{9} / \mathrm{L}\right]\end{array}$ & $791.3 \pm 441.3$ & $440.4 \pm 283.4$ & 0.007 \\
\hline $\begin{array}{l}\text { Hemoglobin } \\
\text { Mean } \pm \text { SD }[\mathrm{g} / \mathrm{L}]\end{array}$ & $116.0 \pm 19.1$ & $107.9 \pm 32.5$ & NS \\
\hline
\end{tabular}

Table 3. Clinical parameters at diagnosis of CML patients in chronic phase expressing normal and elevated levels of $M D R 1$ gene.

\begin{tabular}{|c|c|c|c|}
\hline Parameter & MDR1 $^{(+)}$patients & MDR1 $^{(-)}$patients & $\mathbf{P}$ \\
\hline Patients [n=] & 48 [49.5\%] & 49 [50.5\%] & \\
\hline $\begin{array}{l}\text { Age } \\
\qquad \text { Mean } \pm \text { SD [years] }\end{array}$ & $52.4 \pm 15.4$ & $48.7 \pm 12.6$ & NS \\
\hline $\begin{array}{l}\text { Patients } \\
\quad>60 \text { years }[n=] \\
<60 \text { years }[n=]\end{array}$ & $\begin{array}{l}24 / 34[71 \%] \\
24 / 63[38 \%]\end{array}$ & $\begin{array}{l}10 / 34[29 \%] \\
39 / 63[62 \%]\end{array}$ & 0.008 \\
\hline $\begin{array}{l}\text { Gender } \\
\text { Males }[\mathrm{n}=] \\
\text { Females }[\mathrm{n}=]\end{array}$ & $\begin{array}{l}27[56 \%] \\
21[44 \%]\end{array}$ & $\begin{array}{l}32[65 \%] \\
17[35 \%]\end{array}$ & NS \\
\hline $\begin{array}{l}\text { BCR-ABL transcripts } \\
\text { b3a2 }[n=] \\
\text { b2a2 }[n=]\end{array}$ & $\begin{array}{l}25[52 \%] \\
23[48 \%]\end{array}$ & $\begin{array}{l}28[57 \%] \\
21[43 \%]\end{array}$ & NS \\
\hline $\begin{array}{l}\text { WBC } \\
\text { Mean } \pm \text { SD }\left[\times 10^{9} / \mathrm{L}\right]\end{array}$ & $105.5 \pm 79.8$ & $143.6 \pm 96.5$ & 0.047 \\
\hline $\begin{array}{l}\text { Platelets } \\
\quad \text { Mean } \pm \text { SD }\left[\times 10^{9} / \mathrm{L}\right]\end{array}$ & $647.2 \pm 447.8$ & $591.0 \pm 381.4$ & NS \\
\hline $\begin{array}{l}\text { Hemoglobin } \\
\text { Mean } \pm \text { SD }\end{array}$ & $110.6 \pm 38.6$ & $112.4 \pm 17.2$ & NS \\
\hline
\end{tabular}

Table 4. Clinical and laboratory data of patients with different types of fusion $B C R-A B L$ transcripts and $M D R 1$ expression.

\begin{tabular}{|c|c|c|c|c|c|}
\hline \multirow[t]{2}{*}{ Parameter } & \multicolumn{2}{|c|}{ MDR1(+) patients } & \multirow[t]{2}{*}{$\mathbf{P}$} & \multicolumn{2}{|c|}{ MDR1(-) patients } \\
\hline & $\begin{array}{c}\mathrm{b} 3 \mathrm{a} 2 \\
{[\mathrm{n}=25]}\end{array}$ & $\begin{array}{c}\mathrm{b} 2 \mathrm{a} 2 \\
{[\mathrm{n}=23]}\end{array}$ & & $\begin{array}{c}\text { b3a2 } \\
{[\mathrm{n}=28]}\end{array}$ & $\begin{array}{c}\mathrm{b} 2 \mathrm{a} 2 \\
{[\mathrm{n}=21]}\end{array}$ \\
\hline Age: mean \pm SD [years] & $53.0 \pm 15.2$ & $51.6 \pm 16.0$ & NS & $49.3 \pm 12.1$ & $47.9 \pm 13.6 \mathrm{NS}$ \\
\hline $\begin{array}{l}\text { Patients } \\
>55 \text { years }[n=] \\
<55 \text { years }[n=]\end{array}$ & $\begin{array}{l}12 \text { [48\%] } \\
13 \text { [52\%] }\end{array}$ & $\begin{array}{l}12[52 \%] \\
11[48 \%]\end{array}$ & NS & $\begin{array}{r}7[25 \%] \\
21[75 \%]\end{array}$ & $\begin{array}{cc}5[24 \%] & \text { NS } \\
16[76 \%] & \\
\end{array}$ \\
\hline $\begin{array}{l}\text { Gender } \\
\text { Males }[n=] \\
\text { Females }[n=]\end{array}$ & $\begin{array}{l}11[44 \%] \\
14[56 \%]\end{array}$ & $\begin{array}{l}16[70 \%] \\
7[30 \%]\end{array}$ & NS & $\begin{array}{l}17 \text { [61\%] } \\
11[39 \%]\end{array}$ & $\begin{array}{cc}15[71 \%] & \text { NS } \\
6[29 \%] & \end{array}$ \\
\hline $\begin{array}{l}\text { WBC: } \\
\text { mean } \pm \text { SD }\left[\times 10^{9} / \mathrm{L}\right]\end{array}$ & $85.4 \pm 61.2$ & $130 \pm 93.9$ & 0.004 & $150.8 \pm 86.6$ & $134.6 \pm 109.5 \mathrm{NS}$ \\
\hline $\begin{array}{l}\text { Platelets: } \\
\text { mean } \pm \mathrm{SD}\left[\times 10^{9} / \mathrm{L}\right]\end{array}$ & $908.7 \pm 470.1$ & $472.9 \pm 356.1$ & 0.006 & $727.3 \pm 434.0$ & $403.8 \pm 189.1 \mathrm{NS}$ \\
\hline $\begin{array}{l}\text { Hemoglobin: } \\
\text { mean } \pm \text { SD }[\mathrm{g} / \mathrm{L}]\end{array}$ & $123.5 \pm 18.6$ & $103.1 \pm 46.2$ & NS & $112.7 \pm 19.4$ & $112.1 \pm 15.6 \mathrm{NS}$ \\
\hline
\end{tabular}


tures of $B C R-A B L$-positive CML patients to the type of transcripts. The only variable, that showed significant difference between the two groups, was the platelet count, which was significantly higher in patients who expressed $\mathrm{b} 3 \mathrm{a} 2$, providing additional evidence that $\mathrm{b} 3 \mathrm{a} 2$ transcripts seem to be associated with a higher thrombopoietic activity in CML. ${ }^{7-9}$

In addition, the most interesting finding in our study was that the significant correlation between the elevated platelets count and $\mathrm{b} 3 \mathrm{a} 2$ transcripts compared to b2a 2 was restricted only to the subgroup of patients with $M D R 1$ over-expression, Moreover, the MDRI overexpression status outlined a significant association between the WBC count and the type of transcripts as we observed lower counts in the b3a2-positive cases compared to b2a2. No similar differences were found between b3a2- and b2a2-positive patients within the subgroup with normal $M D R 1$ levels.

A possible explanation is that the significant differences in the platelets and WBC count in patients with b3a2 and b2a2 transcripts only in patients with MDR1 over-expression reflect a preferential activation of a common specific signaling cascade in the b3a2-positive cases, which is not active in the remaining patients. This might be related to variations in the level of $B C R-A B L$ transcripts, since a dose-dependent hierarchy of $B C R-A B L$ induced activation of signaling pathways and biological effects exists. ${ }^{25}$ Moreover, it has been reported that b3a2 transcripts may affect the thrombopoietic activity in CML also in a dose-response manner. ${ }^{7}$ Alternatively, it might be also possible that MDR1 over-expression due to additional molecular abnormalities might interfere with differences in the structure of two p $210^{\mathrm{Bcr}-\mathrm{Abl}}$ proteins preferentially promoting the interaction of b3a2 with the cytoskeleton of megakaryocytes $^{8}$ resulting in the particular CML phenotype presented by thrombocytosis and relatively lower leukocytosis.

However, this hypothesis is only speculative and needs to be confirmed because the precise molecular mechanisms that underline an elevated MDRI expression in untreated CML patients are still unknown. In general, data concerning MDR1 expression in CML are still insufficient and contradictory. Our study provides some interesting information in regard to the incidence of $M D R 1$ over-expression and the related patients' characteristics. We found elevated levels in approximately $50 \%$ of untreated patients. This result was in agreement with the data, reported earlier by Giles et al. (1999) and Weide et al. (1990), who using alternative methods revealed high levels of MDR1/P-gp expression in $57 \%$ and $41 \%$ of CML cases, respectively. ${ }^{14,26}$ In our study, there were no differences in the prevalence of the different types of transcripts, as well as in the gender, platelets count and hemoglobin level between patients with normal and elevated levels of $M D R 1$. However, the incidence of $M D R 1$ gene over-expression was significantly more frequent among the older patients. Similar results were observed not only in chronic phase CML patients, ${ }^{14}$ but also in acute leukemias. ${ }^{27,28}$ Moreover, an age-related increase of P-gp expression was found on peripheral blood cells of healthy individuals. ${ }^{29}$ All these data suggest that common biological factors may contribute to the drug resistance in the elderly.

Additionally, we and others ${ }^{14}$ found that MDR1 over-expression in CML was associated with a lower WBC count compared to the patients with normal MDR1 levels. Interestingly, in acute leukemias, the MDR1 over-expression has been reported to be associated with hyperleukocytosis, both in AML ${ }^{27}$ and ALL. ${ }^{28}$ To our knowledge, no explanation for these differences has been reported so far.

Some observations suggest that the MDRI gene over-expression in CML might be one of multiple cellular alterations caused by the p210 ${ }^{B C R-A B L}$. Physiologically, the regulation of $M D R 1$ gene expression involves various signaling pathways (i.e. p53, SP1, NF-Y, AP-1, NF-kB, $\mathrm{C} / \mathrm{EBP}$ and RAS) ${ }^{30} \mathrm{~A}$ key role in this process plays Jun NH2-terminal protein kinase (JNK), which in response to stress-signals activates the heterodimeric AP-1 transcription factor, which in turn interacts with the MDR1 gene promoters and enhances transcription. ${ }^{31}$ Given that it has been shown that $\mathrm{p} 210^{B C R-A B L}$ may activate most of these pathways, ${ }^{1}$ including $\mathrm{JNK}^{32}$ it seems possible that the hybrid oncoproteins may also affect MDRl expression in this manner. ${ }^{31}$ This hypothesis is also supported by the observation that transduction of normal cells with b3a2 cDNA leads to upregulation of the expression of P-glycoprotein, the product of the MDR1 gene. ${ }^{33}$ Alternatively, the differences in the MDR1 expression in CML patients might be related to defects in the methylation machinery as a distinct molecular pathway leading to malignant transformation ${ }^{34}$ or might be a random event associated with nucleotide and/or haplotype variants of the MDR1 gene, which seems to be important for interindividual differences of its expression. ${ }^{35-38}$

In conclusion, our preliminary results indicate that the type of $B C R-A B L$ transcripts correlates with the hematological parameters of CML patients, however only in the subgroup of patients characterized by over-expression of MDR1 gene. Further studies need to elucidate the molecular events underlying the relationship between the type of $B C R$ - $A B L$ transcripts and expression of $M D R 1$ gene in CML.

\section{References}

1. Quintás-Cardama A, Cortes J. Molecular biology of $b c r$-abll-positive chronic myeloid leukemia. Blood 2009;113:161930 .

2. de Lemos JA, de Oliveira CM, Scerni AC, et al. Differential molecular response of the transcripts $\mathrm{B} 2 \mathrm{~A} 2$ and $\mathrm{B} 3 \mathrm{~A} 2$ to imatinib mesylate in chronic myeloid leukemia. Genet Mol Res 2005;4:803-11.

3. Lucas CM, Harris RJ, Giannoudis A, et al. Chronic myeloid leukemia patients with the e13a2 BCR-ABL fusion transcript have inferior responses to imatinib compared to patients with the e14a2 transcript. Haematologica 2009;94:1362-7.

4. Sharma P, Kumar L, Mohanty S, Kochupillai V. Response to Imatinib mesylate in chronic myeloid leukemia patients with variant $B C R$-ABL fusion transcripts. Ann Hematol. 2010;89:241-7.

5. Mondal BC, Bandyopadhyay A, Majumdar $\mathrm{S}$, et al. Molecular profiling of chronic myeloid leukemia in eastern India. Am J Hematol 2006;81:845-9.

6. Adler R, Viehmann S, Kuhlisch E, et al. Correlation of $B C R / \mathrm{ABL}$ transcript variants with patients' characteristics in childhood chronic myeloid leukaemia. Eur J Haematol 2009;82:112-8.

7. Inokuchi K, Inoue T, Tojo A, et al. A possible correlation between the type of $b c r$-abl hybrid messenger RNA and platelet count in Philadelphia-positive chronic myelogenous leukemia.Blood 1991;78:3125-7.

8. Perego RA, Costantini M, Cornacchini G, et al. The possible influences of B2A2 and B3A2 BCR/ABL protein structure on thrombopoiesis in chronic myeloid leukaemia. Eur J Cancer 2000;36:1395-401.

9. Verschraegen CF, Kantarjian HM, HirschGinsberg C, et al. The breakpoint cluster region site in patients with Philadelphia chromosome-positive chronic myelogenous leukemia. Clinical, laboratory, and prognostic correlations. Cancer 1995;76: 992-7.

10. Rozman C, Urbano-Ispizua A, Cervantes F, et al. Analysis of the clinical relevance of the breakpoint location within $\mathrm{M}-B C R$ and the type of chimeric mRNA in chronic myelogenous leukemia. Leukemia 1995;9: 1104-7.

11. Opalka B, Wandl UB, Kloke O, et al. No correlation between site of breakpoint in the $B C R$ gene and platelet counts in Philadelphia chromosome-positive CML. Leuk Res 1992;16:937-9.

12. Melo J. The diversity of $B C R$-ABL fusion proteins and their relationship to leukemia phenotype. Blood 1996;88:237584. 
13. Shepherd P, Suffolk R, Halsey J, Allan N. Analysis of molecular breakpoint and $\mathrm{m}$ RNA transcripts in a prospective randomized trial of interferon in chronic myeloid leukaemia: no correlation with clinical features, cytogenetic response, duration of chronic phase, or survival. Br J Haematol 1995;89:546-54.

14. Giles FJ, Kantarjian HM, Cortes J, et al. Multidrug resistance protein expression in chronic myeloid leukemia: associations and significance. Cancer 1999;86:805-13.

15. Leonard GD, Fojo T, Bates SE. The role of $\mathrm{ABC}$ transporters in clinical practice. Oncologist 2003;8:411-24.

16. Nüssler V, Pelka-Fleischer R, Zwierzina H, et al. Clinical importance of P-glycoprotein-related resistance in leukemia and myelodysplastic syndromes--first experience with their reversal. Ann Hematol 1994;69:S25-9.

17. Sato H, Gottesman MM, Goldstein LJ, et al. Expression of the multidrug resistance gene in myeloid leukemias. Leuk Res 1990;14:11-21.

18. Stavrovskaya A, Turkina A, Sedyakhina N, et al. Prognostic value of P-glycoprotein and leukocyte differentiation antigens in chronic myeloid leukemia. Leuk Lymphoma 1998;28:469-82.

19. Michelutti A, Michieli M, Damiani D, et al. Overexpression of MDR-related p170 glycoprotein in chronic myeloid leukemia. Haematologica 1994;79:200-4.

20. Herweijer H, Sonneveld P, Baas F, Nooter K.Expression of mdr1 and mdr3 multidrugresistance genes in human acute and chronic leukemias and association with stimulation of drug accumulation by cyclosporine. J Natl Cancer Inst 1990;82:1133-40.

21. Isotalo PA, Wells GA, Donnelly JG. Neonatal and fetal methylenetetrahydrofolate reductase genetic polymorphisms: an examination of C677T and A1298C muta- tions. Am J Hum Genet 2000;67:986-90.

22. van Dongen JJ, Macintyre EA, Gabert JA, et al. Standardized RT-PCR analysis of fusion gene transcripts from chromosome aberrations in acute leukemia for detection of minimal residual disease. Report of the BIOMED-1 Concerted Action: investigation of minimal residual disease in acute leukemia. Leukemia. 1999;13:1901-28.

23. Veelken H, Licht T, Lais A, et al. Drug resistance of secondary acute myeloid leukemia with megakaryoblastic features and p190 BCR-ABL rearrangement. Leuk Res 1998;22:1021-7.

24. Kwok S, Higuchi R. Avoiding false positives with PCR. Nature 1989; 18;339:237-8.

25. Cambier N, Chopra R, Strasser A, et al. BCR-ABL activates pathways mediating cytokine independence and protection against apoptosis in murine hematopoietic cells in a dose-dependent manner. Oncogene 1998;16:335-48.

26. Weide R, Dowding C, Paulsen W, Goldman $\mathrm{J}$. The role of the MDR-1/P-170 mechanism in the development of multidrug resistance in chronic myeloid leukemia. Leukemia 1990;4:695-9.

27. Leith CP, Kopecky KJ, Chen IM, et al. Frequency and clinical significance of the expression of the multidrug resistance proteins MDR1/P-glycoprotein, MRP1, and LRP in acute myeloid leukemia: a Southwest Oncology Group Study. Blood 1999;94:1086-99.

28. Damiani D, Michelutti A, Michieli M, et al. P-glycoprotein, lung resistance-related protein and multidrug resistance-associated protein in de novo adult acute lymphoblastic leukaemia. Br J Haematol 2002;116:519-27.

29. Svoboda-Beusan I, Kusec R, Bendelja K, et al. The relevance of multidrug resistanceassociated P-glycoprotein expression in the treatment response of B-cell chronic lymphocytic leukemia.Haematologica
2000;85:1261-7.

30. Schaich M, Illmer T. Mdr1 gene expression and mutations in Ras proto-oncogenes in acute myeloid leukemia. Leuk Lymphoma. 2002;43:1345-54.

31. Sukhai M, Piquette-Miller M. Regulation of the multidrug resistance genes by stress signals. J Pharm Pharm Sci 2000;3:268-80.

32. Raitano AB, Halpern JR, Hambuch TM, Sawyers CL. The Bcr-Abl leukemia oncogene activates Jun kinase and requires Jun for transformation. Proc Natl Acad Sci U S A 1995;92:11746-50.

33. Fan E, Hu Y, Zhao C. Human stem cell model to study signal transduction and molecular regulation mechanisms in CML. Chin Med J (Engl) 2001;114:680-4.

34. Garcia-Manero G, Daniel J, Smith TL, et al. DNA methylation of multiple promoterassociated $\mathrm{CpG}$ islands in adult acute lymphocytic leukemia. Clin Cancer Res 2002;8:2217-24.

35. Takane Takane H, Kobayashi D, Hirota T, et al. Haplotype-oriented genetic analysis and functional assessment of promoter variants in the MDR1 (ABCB1) gene. $\mathrm{J}$ Pharmacol Exp Ther 2004;311:1179-87.

36. Illmer T, Schuler US, Thiede C, et al. MDR1 gene polymorphisms affect therapy outcome in acute myeloid leukemia patients. Cancer Res 2002;62:4955-62.

37. Taheri M, Mahjoubi F, Omranipour R. Effect of MDR1 polymorphism on multidrug resistance expression in breast cancer patients. Genet Mol Res 2010;9:34-40.

38. Illmer T, Schaich M, Platzbecker U, et al. Pglycoprotein-mediated drug efflux is a resistance mechanism of chronic myelogenous leukemia cells to treatment with imatinib mesylate. Leukemia 2004;18:4018. 